\title{
Biologic effects of SMF and paclitaxel on K562 human leukemia cells
}

\author{
Run-Guang Sun ${ }^{1}$, Wen-Fang Chen ${ }^{1}$, Hao Qi ${ }^{2}$, Kun Zhang ${ }^{2}$, Ting Bu², Ying Liu ${ }^{1}$ and Shu-Rui \\ Wang ${ }^{2}$ \\ ${ }^{1}$ College of Physics and Information Technology, Shaanxi Normal University, Xian, Shaanxi 710062, P. R. China \\ ${ }^{2}$ College of Life Sciences, Shaanxi Normal University, Xian, Shaanxi 710062, P. R. China
}

\begin{abstract}
In this study, we evaluated the ability of $8.8 \mathrm{mT}$ static magnetic fields (SMF) to enhance the in vitro action of a chemotherapeutic agent, paclitaxel, against K562 human leukemia cells. We analyzed the cell proliferation, cell cycle distribution, DNA damage and alteration of cell surface and cell organelle ultrastructure after K562 cells were exposed to paclitaxel in the presence or absence of $8.8 \mathrm{mT}$ SMF. The results showed that in the presence of SMF, the efficient concentration of paclitaxel on K562 cells was decreased from 50 to $10 \mathrm{ng} / \mathrm{ml}$. Cell cycle analysis indicated that K562 cells treated with SMF plus paclitaxel were arrested at the G2 phase, which was mainly induced by paclitaxel. Through comet assay, we found that the cell cycle arrest effect of paclitaxel with or without SMF on K562 cells was correlated with DNA damage. The results of atomic force microscopy and transmission electron microscopy observation showed that the cell ultrastructure was altered in the group treated with the combination of SMF and paclitaxel, holes and protuberances were observed, and vacuoles in cytoplasm were augmented. Our data indicated that the potency of the combination of SMF and paclitaxel was greater than that of SMF or paclitaxel alone on K562 cells, and these effects were correlated with DNA damage induced by SMF and paclitaxel. Therefore, the alteration of cell membrane permeability may be one important mechanism underlying the effects of SMF and paclitaxel on K562 cells.
\end{abstract}

Key words: Biological effects - Paclitaxel - SMF - Cell cycle - DNA damage

\section{Introduction}

Previous studies suggest that static magnetic fields (SMF) or pulsed magnetic fields (PMF) can enhance the cytotoxic effects of antitumor drug on tumor cells cultured in vitro or in vivo (Hannan et al. 1994; Gray et al. 2000; Ruiz-Gomez et al. 2002). For example, Tofani and his colleagues (Tofani et al. 2003) reported that the survival time of mice treated with the combination of cisplatin and $3 \mathrm{mT} \mathrm{SMF}$ is significantly longer than that of mice treated with cisplatin or SMF alone after mice are cultivated with murine Lewis lung carcinomas (LLCs). In the in vitro cell growth assay, the application of $1 \mathrm{~T}$ SMF, which is combined with a mixture of antineoplastic drugs (5-fluorouracil, cisplatin, doxorubicin and vincristine) for $72 \mathrm{~h}$ on HL-60 cells, enhances the cytotoxic effect of an-

Correspondence to: Hao Qi, College of Life Sciences, Shaanxi Normal University, 199 South Chang'an Road, Xi'an, Shaanxi 710062, P. R. China

E-mail: qhsnnu@126.com tineoplastic drugs (Sabo et al. 2002). These findings indicate that the cytotoxic effects of SMF/PMF plus antitumor drugs are stronger than those of SMF/PMF or chemotherapeutic drugs alone. Therefore, a potential strategy for chemotherapy is to use the combined or synergic effects of magnetic fields and antitumor drugs to either intensify the cytotoxic effects of chemotherapeutic drugs on tumor cells or reduce drug dosage for decreasing side-effects of chemotherapeutic drugs. In order to explore the strategy, we first investigated whether and how SMF/PMF and drugs contribute to enhance the cytotoxicity of drugs on tumor cells. Second, we investigated the mechanism of these effects. Although some studies have reported that the cytotoxic effects of SMF/PMF combined with antineoplastic drugs are more effective. However, the mechanism of the effects remains unclear. We used a SMF, a simple and basic magnetic field, to investigate the biological effects and explore the possible mechanism of the cytotoxic effects on K562 human leukemia cells induced by SMF and paclitaxel.

Paclitaxel has been regarded as one of the most potent antitumor drugs, and it was introduced into medical prac- 
tice several decades ago. Paclitaxel structures contain an eight-member taxane ring with a four-member oxetane ring and a bulky ester side chain at C-13 that is necessary for antitumor activity (Kumar 1981; Horwitz et al. 1986; Pushkarev et al. 2004). Antitumor activity of paclitaxel result from its binding to assembled microtubules and the related stabilization effect, which disrupts the equilibrium between tubulin submit and microtubules, leading to cell death (Horwitz 1992; Rao et al. 1992; Jordan et al. 1993; Pushkarev et al. 2004).

In this study, we measured the effect of paclitaxel (with or without SMF) at different concentrations on K562 cells by 3-(4,5-dimethylthiazol-2-yl)-2,5-diphenyl-tetrazolium bromide (MTT) assay. In order to investigate the possible mechanism of these effects, we further examined cell cycle distribution, DNA damage, change of surface and interior ultrastructure.

\section{Materials and Methods}

\section{Cell cultures}

K562 cells (ATCC, CCL-243) were purchased from the Chinese Academy of Sciences Cell Bank of Type Culture Collection Committee. The cells were maintained in RPMI-1640 medium (Sigma-Aldrich, USA) supplemented with 10\% fetal bovine serum (Gibco, USA) and $1 \mathrm{mmol} / \mathrm{l} \mathrm{L}$-glutamine at $37^{\circ} \mathrm{C}$ in a humidified $5 \%(\mathrm{v} / \mathrm{v}) \mathrm{CO}_{2}$ incubator. Cells in logarithmic phase were used for the experiments.

\section{SMF application}

The SMF exposure system was described previously (Qi et al. 2011). Briefly, the SMF was produced by a solenoid. It was made of copper wire wound around a ring former with dimensions of $4 \mathrm{~cm}$ radius and $54.7 \mathrm{~cm}$ length. The power source was a direct current power supply (WYJ, Shanghai voltage regulator plant, Shanghai, China). This device produced a homogeneous SMF in a volume close to the axis with a calculated magnetic flux intensity of $9 \mathrm{mT}$. The value of magnetic flux density was $8.800 \pm 0.106 \mathrm{mT}$ as measured by a gauss meter (HT20, Hengtong magnetoelectricity, Shanghai, China). The water flow from a cooling bath was circulated through a tube surrounding the solenoid to disperse the Joule effect. A non-magnetic and airtight incubator ( $25 \mathrm{~cm}$ length, $5 \mathrm{~cm}$ width, and $5 \mathrm{~cm}$ height) was used to place the samples within the middle of solenoid. The samples were placed on the bottom of the incubator. Temperature in the incubator was monitored by a heater and a thermo-controller to keep the incubator temperature constant at $36.5 \pm 0.5^{\circ} \mathrm{C}$. Then, $32 \mathrm{ml}$ of $\mathrm{CO}_{2}$ was insufflated into the incubator to maintain the $\mathrm{pH}$ of medium between 7.2-7.4. Pre-testing results showed that the proliferation of cells incubated in this incubator was similar to that of cells cultured in the $\mathrm{CO}_{2}$ incubator $(p>0.05)$. Figure 1 summa-

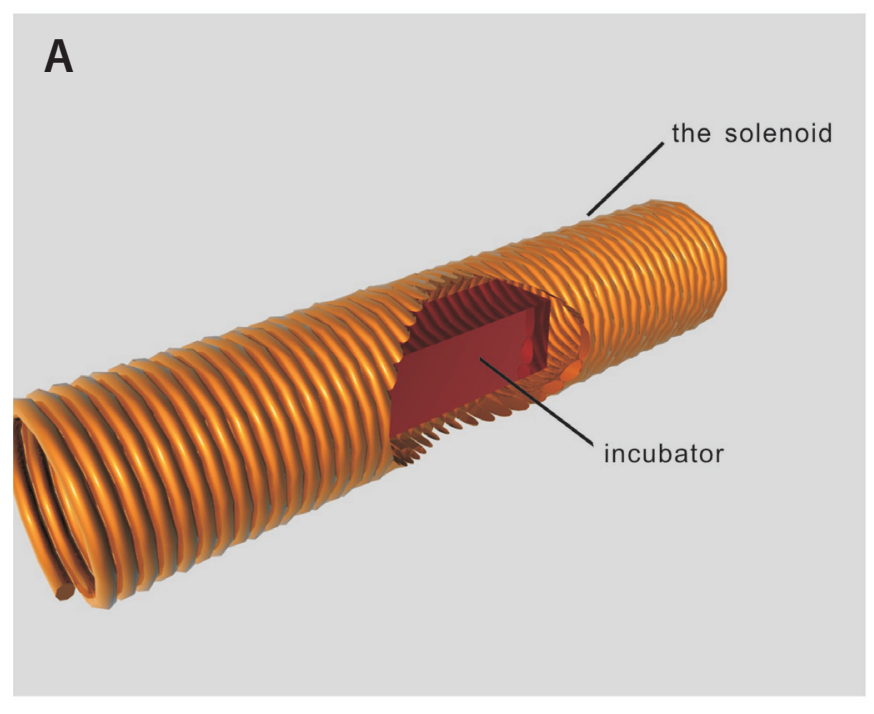

B

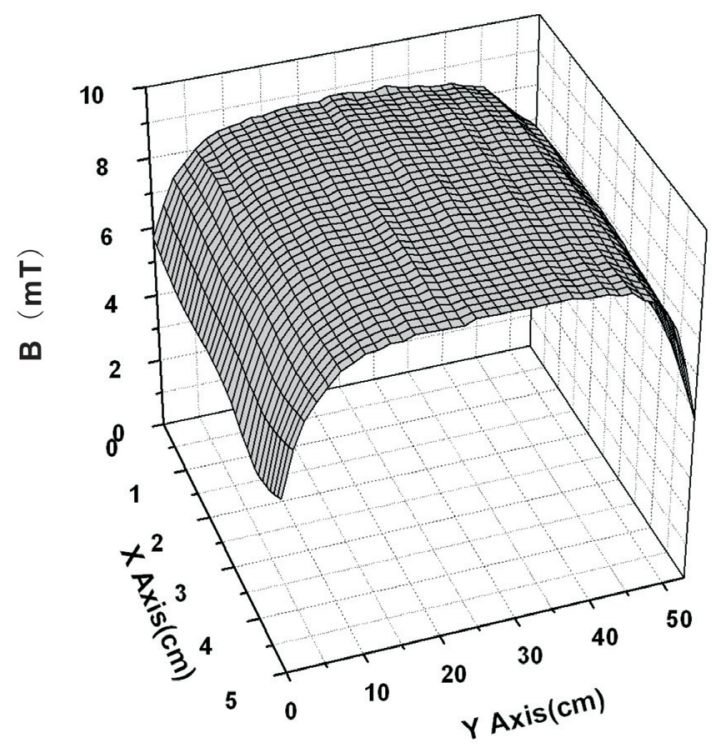

Figure 1. A. Sketch map of the static magnetic field (SMF) exposure system. A non-magnetic and airtight incubator $(25 \mathrm{~cm}$ length, $5 \mathrm{~cm}$ width, and $5 \mathrm{~cm}$ height) was used to place the samples within the middle of solenoid ( $4 \mathrm{~cm}$ radius, $54.7 \mathrm{~cm}$ length). Temperature in the incubator was monitored by a heater and a thermo-controller to keep the incubator at a constant temperature $\left(36.5 \pm 0.5^{\circ} \mathrm{C}\right)$. Samples were placed at the bottom of the incubator. For more details see Materials and Methods. B. Distribution of SMF flux density, which was measured along the center axis at the floor level of the cell culture bottles. 
rizes the exposure position and magnetic flux density at the floor level of the incubator. For the sham-exposure system, a unit with the same coil shape and the incubator was used but without the SMF generator. Temperature, $\mathrm{CO}_{2}$ and $\mathrm{pH}$ were same with the real exposure. After being measured by a gauss meter, the actual value of the magnetic flux intensity produced by heater and all other devices is $0.020 \pm 0.005 \mathrm{mT}$. In each experiment, sham- and real exposure were performed simultaneously.

\section{Experimental group}

K562 cells at the logarithmic phase were inoculated at a density of $1 \times 10^{5}$ cells $/ \mathrm{ml}$ into cell culture bottles, and they were randomly divided into the following groups: 1) sham-exposed group: cells were incubated in sham-exposed system for $24 \mathrm{~h}$; 2) SMF-treated group: cells were continuously exposed to SMF for $24 \mathrm{~h}$; 3 ) paclitaxel group: cells were incubated with paclitaxel at different concentrations $(10,20$, 50 and $100 \mathrm{ng} / \mathrm{ml}$ ) for $24 \mathrm{~h}$; 4) SMF+paclitaxel group: cells were treated with SMF plus paclitaxel described as above.

\section{MTT assay}

The cytotoxicity was monitored by MTT assay according to the Mosmann's protocol (Mosmann 1983). Briefly, cell suspensions were cultivated in 96-well cell culture clusters (Costar, USA) at a final volume of $100 \mu \mathrm{l}$. Subsequently, MTT (1 mg/ml, Sigma-Aldrich, USA) was added to each sample. The cells were maintained at $37^{\circ} \mathrm{C}$ in a humidified atmosphere with $5 \% \mathrm{CO}_{2}$ for $4 \mathrm{~h}$. During this period, the living cells produced a blue insoluble formazan product from the yellow soluble MTT. The cellular metabolic activity was directly associated with the amount of MTT-formazan product formation. After the crystals were solubilized in $0.2 \mathrm{ml}$ of dimethyl sulfoxide (DMSO), the optical density (OD) was measured at $570 \mathrm{~nm}$ by a spectrophotometer (Model 680 microplate reader, Bio-Rad Laboratories, USA). Each group included 6-8 wells, and the experiment was done in triplicate.

\section{Guava ViaCount assay}

The Guava ViaCount assay is a rapid and reliable alternative to trypan blue exclusion for determining cell count and viability. The ViaCount reagent differentially stains viable and non-viable cells based on their permeability to the DNA-binding dyes in the reagent, allowing the quantitative assessment of viable and non-viable nucleated cells present in a suspension. The system counts the stained nucleated events, then uses the forward scatter (FSC) properties to distinguish free nuclei and cellular debris from cells to determine an accurate cell count.
To run the assay, the samples were stained with the Guava ViaCount reagent (Millipore, USA) according to the instructions in the Guava PCA ${ }^{\mathrm{TM}}-96$ ViaCount Reagent package insert. Briefly, cell suspensions were cultivated in 96-well cell culture clusters (Costar, USA) at a final volume of $25 \mu$ l. Subsequently, the Guava ViaCount reagent with a final volume of $225 \mu \mathrm{l}$ was added to each sample. The samples were stained for $5 \mathrm{~min}$ and detected by the guava easyCyte HT System (Millipore, USA) using guavaSoft Software.

\section{Cell cycle analysis}

The cells were harvested by centrifugation and washed in phosphate-buffered saline (PBS), and cells were fixed in 70\% ethanol at $4^{\circ} \mathrm{C}$ overnight. The samples were stained with DNA prep reagents kit (Beckman Counter, USA) in darkness at $25^{\circ} \mathrm{C}$ for $25 \mathrm{~min}$ and detected by FACScalibur (Becton Dickinson, USA). The data from $2 \times 10^{4}$ cells was analyzed on Mod Fit LT for Mac V 3.0 software (Verity House, USA). The experiment was conducted in triplicate.

\section{Alkaline comet assay}

Prior to the experiment, slides were coated with $0.2 \%$ agarose. A clean cover slip was placed on the slide to build a $22 \times$ $10 \times 0.17 \mathrm{~mm}$ small gap. After K562 cells were treated with SMF and/or paclitaxel, cells were collected by centrifugation $(400 \times g, 3 \mathrm{~min})$, and the cell density was adjusted to $3 \times 10^{5}$ cells/ml with PBS. According to the modified comet assay protocol (Chen et al. 2010), approximately $3 \times 10^{4}$ cells in $0.1 \mathrm{ml}$ PBS were mixed with $0.1 \mathrm{ml} 1 \%$ low-melting-point agarose (Sigma-Aldrich, USA). The mixture was placed into the $22 \times 10 \times 0.17 \mathrm{~mm}$ gap. The cover glasses were carefully removed after the agarose layer was polymerized. Subsequently, the layer was treated with lysis buffer $(2.5$ $\mathrm{mol} / \mathrm{l} \mathrm{NaCl}, 100 \mathrm{mmol} / \mathrm{l}$ EDTA, $10 \mathrm{mmol} / \mathrm{l}$ Tris, $200 \mathrm{mmol} / \mathrm{l}$ $\mathrm{NaOH}, 1 \% \mathrm{~N}$-lauroyl-sarcosine, pH 10; $1 \%$ Triton and 10\% DMSO were added immediately before use) at $4^{\circ} \mathrm{C}$ for 60 min. After the cells were lysed, the slides were washed with triple-distilled water for three times at $4^{\circ} \mathrm{C}$. The lysed cells were then placed in an electrophoresis chamber, exposed to alkali (300 mmol/l NaOH, $1 \mathrm{mmol} / \mathrm{l} \mathrm{EDTA}, \mathrm{pH} 13)$ at $4^{\circ} \mathrm{C}$ for $20 \mathrm{~min}$ and electrophoresed at $4^{\circ} \mathrm{C}$ for $20 \mathrm{~min}$ at 0.86 $\mathrm{V} / \mathrm{cm}$. After the electrophoresis, the slides were washed in $0.4 \mathrm{~mol} / \mathrm{l}$ Tris- $\mathrm{HCl}$ ( $\mathrm{pH} 7.4$ ) for three times at $4^{\circ} \mathrm{C}$. The slides were subsequently dried with $90 \%$ and $100 \%$ ethanol, stained with $20 \mu \mathrm{g} / \mathrm{ml}$ ethidium bromide (Sigma-Aldrich, USA) and imaged with a fluorescence microscope (Digital Sight DS-L1, Nikon Corporation, Japan). Images were analyzed with CASP software (Hellman et al. 1995; Konca et al. 2003). A total of 150 cells were evaluated for each experimental group from three different slides, and the cellular DNA 
damage was calculated by visualized tail moment (TM) and Olive tail moment (OTM) (Collins 2004).

\section{Atomic force microscope (AFM) observation}

AFM (SPM-9500J3 with WET CNII; Shimadzu, Japan) was operated in air. V-shaped $\mathrm{Si}_{3} \mathrm{~N}_{4}$ cantilever (Olympus OMCLTR800PSA-1, Japan) with $0.12 \mathrm{~N} / \mathrm{m}$ spring constant was used in the experiments. The scan rate was adjusted between $1.0 \mathrm{~Hz}$ and $1.5 \mathrm{~Hz}$ in a contact mode. Images obtained were processed by custom software.

According to the modified protocol by Zhuang (Zhuang et al. 2005), cells were gently rinsed with the PBS ( $\mathrm{pH} 7.2$, $0.1 \mathrm{~mol} / \mathrm{l}$ ) twice. Then the cells were fixed by $1 \%$ glutaraldehyde for 15 min and gently rinsed with PBS ( $\mathrm{pH} 7.2$, $0.1 \mathrm{~mol} / \mathrm{l}$ ) twice. The cell density was adjusted to $1 \times 10^{6}$ cells $/ \mathrm{ml}$. The cell suspension was dropped onto the surface of freshly cleaved mica (the size of mica was fitted to the size of the sample holder). After airing, the mica was mounted on the AFM stage and observed under the contact mode of the AFM in air. The average roughness (Ra) was analyzed by the software equipped with the AFM.

\section{Transmission electron microscope (TEM) observation}

TEM analyses of K562 cells were performed according to a method described by Liu (Liu et al. 2003). After the treatment, the cells were rinsed, pelletized and then resuspended in the $0.1 \mathrm{~mol} / \mathrm{l}$ phosphate buffer ( $\mathrm{pH} 7.3$ ) containing $1 \%(\mathrm{v} / \mathrm{v})$ glutaraldehyde at $4^{\circ} \mathrm{C}$ for $2 \mathrm{~h}$. The cells were rinsed three times in a $0.1 \mathrm{~mol} / \mathrm{l}$ phosphate buffer for $10 \mathrm{~min}$. Post-fixed was carried out with $1 \%(\mathrm{w} / \mathrm{v})$ osmium tetroxide, which was prepared in a $0.1 \mathrm{~mol} / \mathrm{l}$ phosphate buffer, for $1-2 \mathrm{~h}$ at room temperature. The cells were then sequentially dehydrated with 50, 75, 95 and $100 \%$ (v/v) ethanol, respectively, for $15 \mathrm{~min}$. Finally, the cells were maintained in $100 \%(\mathrm{v} / \mathrm{v})$ acetone for $20 \mathrm{~min}$. Infiltration was conducted with the mixture of acetone/Epon $812(3: 1)$ for $1 \mathrm{~h}$, the mixture of acetone/Epon $812(1: 1)$ for $1 \mathrm{~h}$, the mixture of acetone/Epon 812 (1:3) for $1 \mathrm{~h}$, and Epon 812 for 24-48 h. Subsequently, the cells were embedded and polymerized at $60^{\circ} \mathrm{C}$ for $24-48 \mathrm{~h}$, sectioned with ultramicrotome and stained with uranyl acetate and lead citrate. The samples were examined under a Hitachi H-600 TEM (Hitachi, Japan). A total of 50 cells were evaluated for each experimental group from five different ultrathin sections. Deformation ratio, as a quantitative data of the TEM observation, is that the ratio between the number of deformation cells and the total number of cells.

\section{Statistical analysis}

Data were analyzed with Bonferroni correction. $p<0.05$ was considered statistically significant. Each experiment was performed at least in triplicate.

\section{Results}

SMF and paclitaxel inhibited the metabolic activity of K562 cells

Figure 2 shows the alteration in metabolic activity of K562 cells, which were treated by SMF with or without paclitaxel. The metabolic activity was significantly decreased $(p<0.05)$ after K562 cells were constantly exposed to SMF for $24 \mathrm{~h}$. The paclitaxel-treated $(50 \mathrm{ng} / \mathrm{ml}, 24 \mathrm{~h}$ ) cells demonstrated a significantly different metabolic activity compared with the controls $(p<0.01)$. The metabolic activity of K562 cells was significantly $(p<0.05)$ lower in the group treated by the combination of SMF and paclitaxel $(10 \mathrm{ng} / \mathrm{ml})$ than that in the other three groups.

Figure 3 shows the change of viability in K562 cells, which were treated by SMF combined with paclitaxel. When K562 cells were treated by SMF $+10 \mathrm{ng} / \mathrm{ml}$ paclitaxel, the viability of cells was slightly but not significantly reduced compared with other three groups $(p>0.05)$. In SMF+paclitaxel $(25 \mathrm{ng} / \mathrm{ml})$ group, the viability of cells was decreased significantly compared with controls and SMF group $(p<0.01)$. With an increase in the concentration of paclitaxel, the inhibition effects of SMF and paclitaxel on viability of cells was more obvious.

These results showed that the combination treatment of SMF and $10 \mathrm{ng} / \mathrm{ml}$ paclitaxel inhibited the metabolic activity of K562 cells.

\section{Effect of combination of SMF and paclitaxel on cell cycle distribution of $\mathrm{K5} 62$ cells}

After the exposure of K562 cells to SMF with or without 10 $\mathrm{ng} / \mathrm{ml}$ paclitaxel for $24 \mathrm{~h}$, we analyzed the cell cycle distribu-

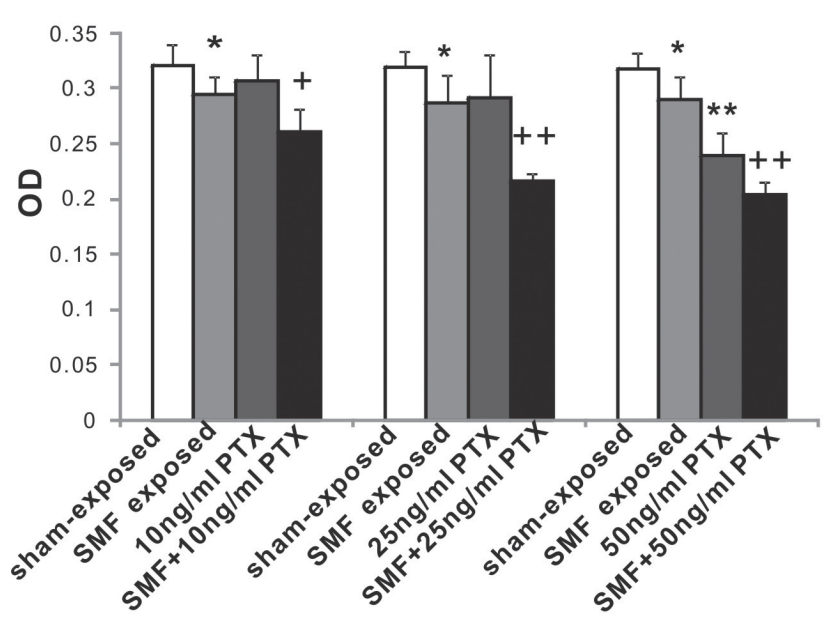

Figure 2. Effect of $8.8 \mathrm{mT}$ SMF combined with paclitaxel on metabolic activity of K562 cells. Bars represent mean \pm SD. $n=6$ ( $n$ represents number of samples). ${ }^{\star} p<0.05,{ }^{* *} p<0.01$, compared with the controls; $+p<0.05,++p<0.01$, compared with the other three groups. OD, optical density; PTX, paclitaxel. 


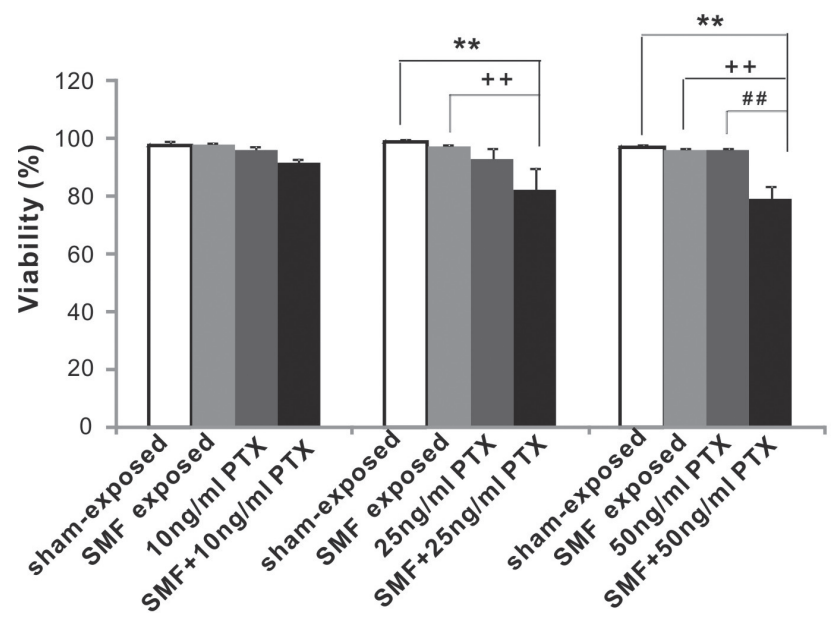

Figure 3. The results of cell count by flow cytometry after K562 cells were exposed to $8.8 \mathrm{mT} \mathrm{SMF}$ combined with paclitaxel. Bars represent mean $\pm \mathrm{SD} ; n=3 .{ }^{* *} p<0.01$, compared with the controls; $++p<0.01$, compared with SMF-exposed groups; \#\# $p<0.01$, compared with PTX group.

tion by flow cytometry (Fig. 4). After the exposure to SMF for $24 \mathrm{~h}$, the G2/M phase cell ratio was significantly increased compared with controls $(p<0.05)$ and the ratios of $\mathrm{G} 1$ phase was significantly lower than controls $(p<0.05)$; while the ratio of $S$ phase was slightly but not significantly increased. The paclitaxel treatment significantly increased the ratio of G2/M phase $(p<0.01)$ and significantly reduced the ratio of $S$ phase compared with controls $(p<0.01)$. In the SMF+paclitaxel group, the ratio of $\mathrm{G} 2 / \mathrm{M}$ phase was increased, there were significantly difference with other three groups $(p<0.05$ or $p<0.01$ ), the proportion of $S$ phase was significantly reduced

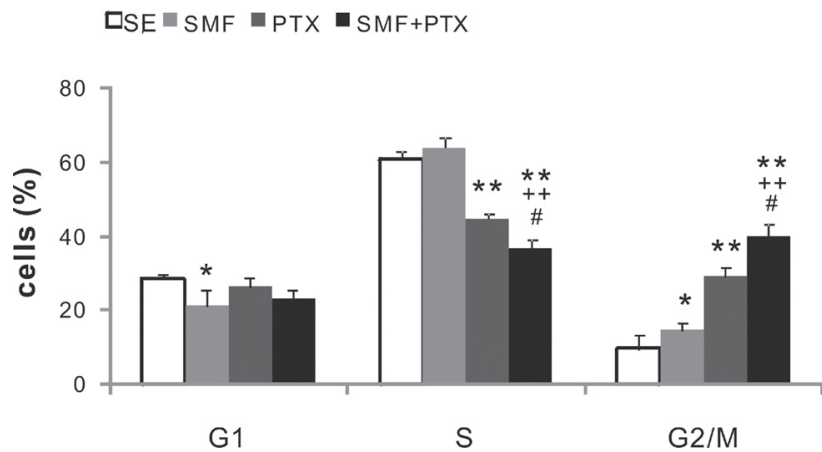

Figure 4. The results of flow cytometry in K562 cells exposed to $8.8 \mathrm{mT}$ SMF with or without $10 \mathrm{ng} / \mathrm{ml}$ paclitaxel. ${ }^{*} p<0.05$, ${ }^{* *} p<0.01$, compared with controls; $++p<0.01$, compared with SMF group; $\# p<0.01$, compared with PTX group $(n=4)$. SE, sham-exposed group; SMF, SMF-exposure group; PTX, paclitaxel group; SMF+PTX, SMF+paclitaxel group. compared with other three groups $(p<0.05$ or $p<0.01)$. These data showed that the proportion of the cells in $\mathrm{G} 2 / \mathrm{M}$ phase could be increased by paclitaxel and/or SMF.

\section{SMF and paclitaxel damaged the cellular DNA of K562 cells}

We used TM and OTM as the parameters to quantify the damage of cellular DNA when K562 cells were exposed to SMF with or without paclitaxel for $24 \mathrm{~h}$ (Fig. 5). Our data showed that the TM and OTM of either SMF or paclitaxel groups were significantly different compared with those of the controls $(p<0.01)$. While the cells were treated by SMF combined with paclitaxel, both TM and OTM were significantly higher than those of the control and paclitaxel groups $(p<0.01)$. However, there was no difference compared with the SMF group $(p>0.05)$. These results suggested that DNA damage was one of the reasons that G2/M phase arrest induced by SMF and paclitaxel.

\section{Cell surface fine structure of combined treatment of K562 cells with SMF plus paclitaxel}

Figure 6 shows the alteration in the cell surface ultrastructure observed by AFM after K562 cells were treated with the combination of SMF and paclitaxel $(10 \mathrm{ng} / \mathrm{ml})$ for $24 \mathrm{~h}$. The cells of the controls had the smooth cell surface with a few minor folds (Fig. 6a). We observed the holes with a diameter of $0.4-0.6 \mu \mathrm{m}$ and different-sized $(0.1-0.5 \mu \mathrm{m})$ apophyses on the cell surface when K562 cells were exposed to the SMF for $24 \mathrm{~h}$ (Fig. 6b). Large and regular apophyses arrayed on the cell surface after K562 cells were incubated with $10 \mathrm{ng} / \mathrm{ml}$ of paclitaxel for $24 \mathrm{~h}$ (Fig. 6c). In the SMF+paclitaxel group, the apophyses on cell surface were too large to display in the image of $5 \times 5 \mu \mathrm{m}$ (Fig. $6 \mathrm{~d}$ ). The image of $10 \times 10 \mu \mathrm{m}$ showed that the cell surface was covered with many round and/or lamellar apophyses (Fig. 6e). The results of average roughness analysis showed that a combination treatment of SMF and paclitaxel significantly increased the membrane surface roughness (Fig. 6B). These data revealed that the damage of cell membrane in the SMF+paclitaxel group was greater than that of the SMF group or paclitaxel group.

\section{Cell organelle ultrastructure of K562 cells treated by the combination of SMF and paclitaxel}

Figure 7 shows the alteration in the cell organelle ultrastructure observed by TEM. In the controls, the cell membrane was integrated, vacuoles in the cytoplasm were occasionally observed, and cell nuclear membrane was integrated (Fig. 7Aa). After the cells were exposed to SMF for $24 \mathrm{~h}$, we found that small vacuoles and many strongly stained granules were randomly distributed in the cytoplasm (Fig. 7Ab). In the paclitaxel group, we observed 
strip-like vacuoles and a few deeply stained cystidiform structures in the cytoplasm, and the cell membrane was inconsecutive (Fig. 7Ac). In the group treated by the combination of SMF and paclitaxel, the number of different-sized vacuoles in the cytoplasm was increased during the $24 \mathrm{~h}$ exposure (Fig. 7Ad). The results of deformation ratio showed that the number of damaged cells in $\mathrm{SMF}+$ paclitaxel group were significantly higher than that of the SMF group or paclitaxel group (Fig. 7B). These data indicated that the effects on K562 cells were enhanced by the combined treatment of SMF and paclitaxel.

\section{Discussion}

Several experiments have been conducted to explore the interaction between SMF/PMF and antitumor drugs on biological systems (Gray et al. 2000; Ruiz-Gomez et al. 2002; Sabo et al. 2002; Tofani et al. 2003). In this study, we reported the biological effects of $8.8 \mathrm{mT} \mathrm{SMF}$ and paclitaxel on human myelogenous leukemia K562 cells in vitro. We found that the cellular metabolic activity was significantly decreased when K562 cells were treated with the combination of SMF and paclitaxel for $24 \mathrm{~h}(p<0.05)$. The results showed that the inhibition effects of SMF combined with paclitaxel on cellular metabolic activity were stronger than those of SMF or paclitaxel alone under the same condition.

Paclitaxel is characterized by stabilizing microtubules, and this feature disrupts the dynamic equilibrium between tubulin subunits and microtubules, resulting in halting cellcycle progression. Our FCM results showed that the cells treated by paclitaxel were blocked at G2/M phase (Figure 3), and this phenomenon also highlighted the especial effects of paclitaxel. Furthermore, DNA can be damaged in a variety of ways, for example, most antitumor drugs or an external source of ionizing radiation can cause DNA damage (Grassi et al. 2004; Wolf et al. 2005). Our results of comet assay showed that DNA damage was increased after the cells were treated with SMF and/or paclitaxel. Therefore, we speculated that the lesions of DNA and microtubules induced by SMF and/or paclitaxel were unfavorable in passing G2/M checkpoint (Kastan and Bartek 2004), and this might be why the proportion of the cells in G2/M phase was increased after the exposure of SMF and/or paclitaxel.

Previous studies show that SMF or electromagnetic fields of extremely low frequency can change the characteristic of cell membrane (Baureus Koch et al. 2003; Chionna et al. 2003). For example, SMF or electromagnetic fields of extremely low frequency enhances the membrane permeability of cells as well as the ability for incepting drug (Hofmann et al. 1999), increases minus charge on the surface of cell membrane (Smith et al. 1991), and changes the distribution of proteins and polysaccharose (Bersani et al. 1997).

In addition, the stabilization of membrane structure is closely correlated to cytoskeleton. Recent studies shows that microtubules and actin filaments contribute to caveolar membrane traffic (Mundy et al. 2002), and help regulate the topography of the plasma membrane in eukaryotic cells (Gundersen 2002; Revenu et al. 2004). The modification on cytoskeleton influences the progressions of transport and organelle location in cells. "However, so far it remains unclear whether such kind of synergistic effect is suit for other tumor cells and whether the combined treatment of SMFs and anticancer drugs affect normal cells" similar as has been shown for extremely low frequency effects (Olsson et al. 2001). In this study, we showed that SMF and/or paclitaxel produced a dramatic modification on cell surface and cell organelle of K562 cells. The cells of the controls had the smooth cell surface with a few minor folds, and the vacuoles were sporadically observed. In the presence of SMF, the holes and apophyses appeared in the cell surface, and the small vacuoles as well as many strongly stained
A

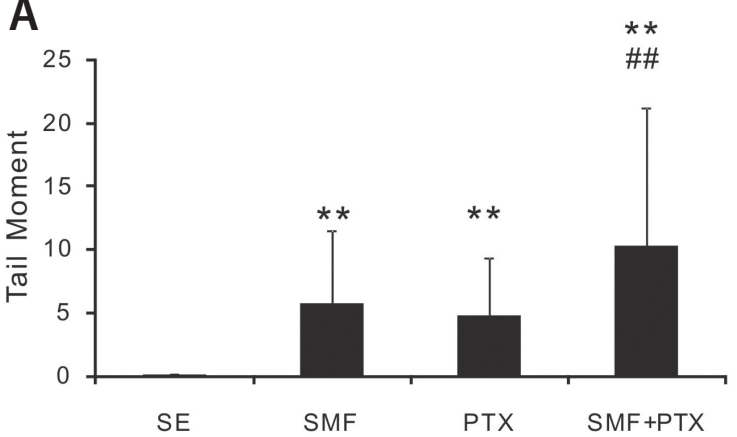

B

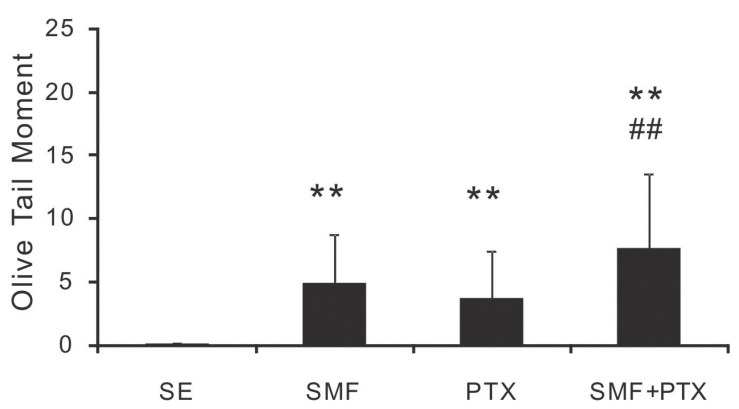

Figure 5. After K562 cells were treated with the combination of SMF and paclitaxel ( $10 \mathrm{ng} / \mathrm{ml})$ for $24 \mathrm{~h}$, DNA damage was detected by the comet assay. Tail Moment (A) and Olive Tail Moment (B) were used as the parameters to quantify the cellular DNA damage. ${ }^{* *} p<$ 0.01 compared with the controls; \#\# $p<0.01$ compared with the paclitaxel-treated group $(n=150)$. 
granules were randomly distributed in the cytoplasm. After K562 cells were incubated in paclitaxel for $24 \mathrm{~h}$, the large and regular apophyses arrayed in the cell surface and strip-like vacuoles, and we observed a few deeply stained cystiform structures in the cytoplasm. After the treatment with a combination of SMF and paclitaxel, the damage of cell membrane was more dramatic and the number of different-sized vacuoles in the cytoplasm was increased. These results suggested that SMF and paclitaxel imposed the effects by destructing cell membrane and organelle

\section{A}
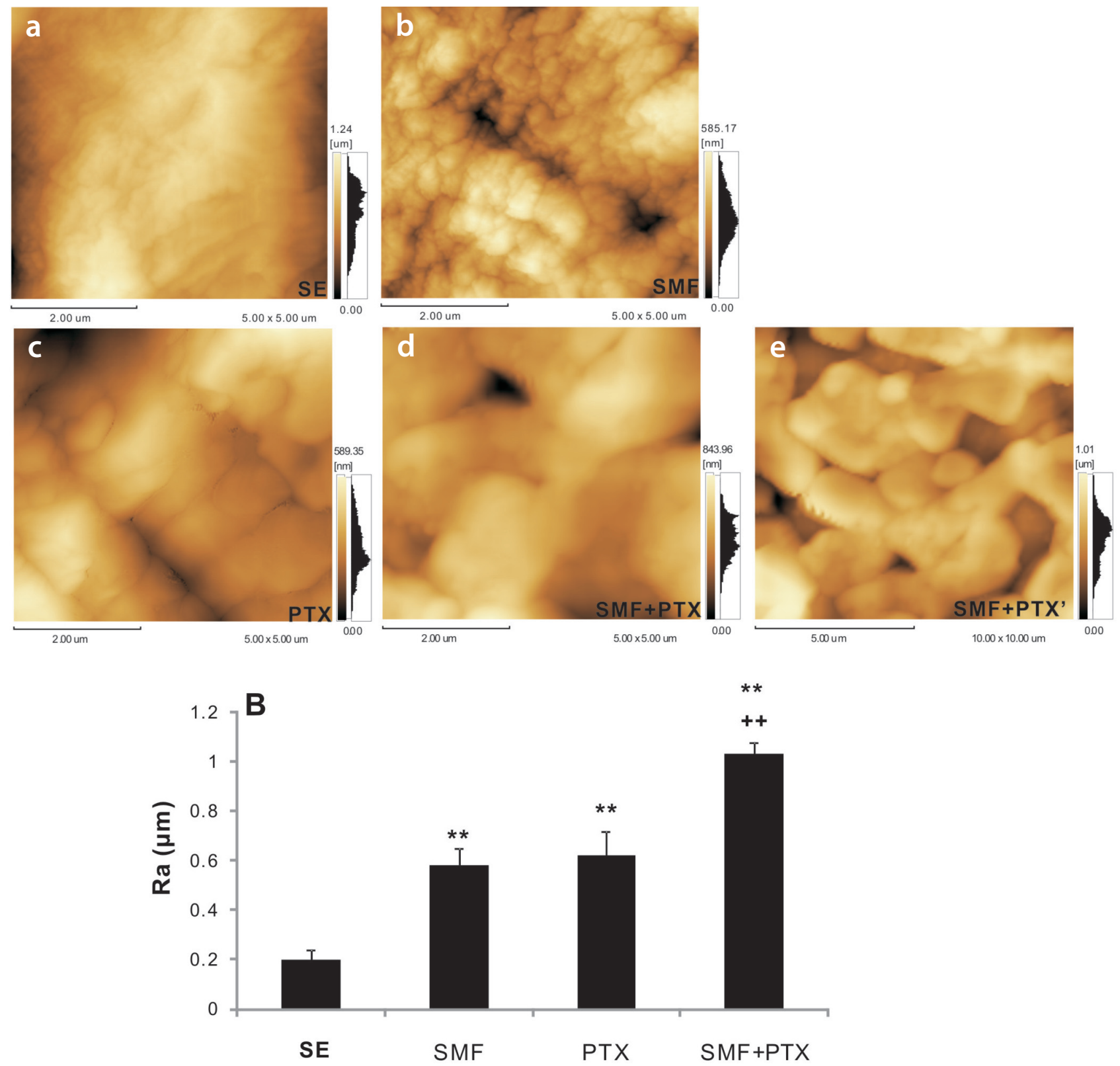

Figure 6. A. Effect of $8.8 \mathrm{mT}$ SMF combined with paclitaxel on cell surface fine structure of K562 cells. We depicted a typical example out of three different experiments. The control cells had the smooth cell surface (a). The exposure of SMF induced the holes and apophyses on the cell surface (b). Large and regular apophyses arrayed on the cell surface after K562 cells were incubated with $10 \mathrm{ng} / \mathrm{ml}$ of paclitaxel for $24 \mathrm{~h}$ (c). The cell surface was covered with many round and/or lamellar apophyses in the SMF+paclitaxel group (d, e). B. Results of the average roughness ( $\mathrm{Ra}$ ) analysis. ${ }^{* *} p<0.01$ compared with the controls; $++p<0.01$ compared with other three groups; $n=5$. Abbreviations see Fig. 4. 
A
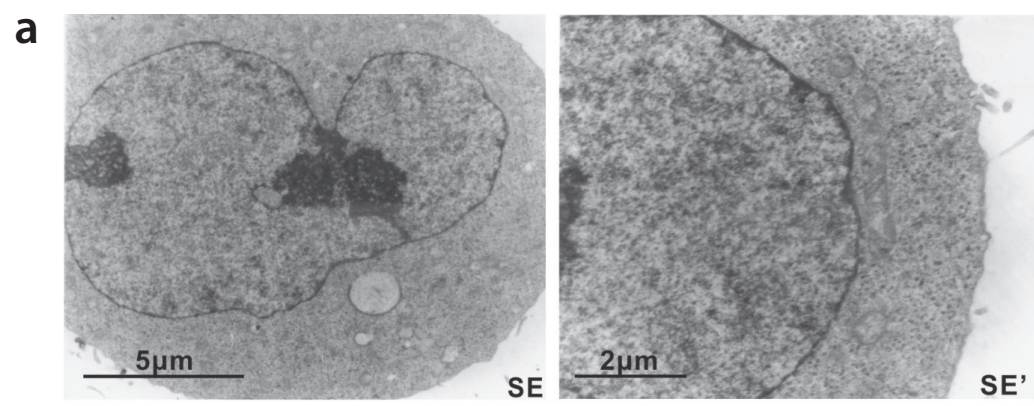

b
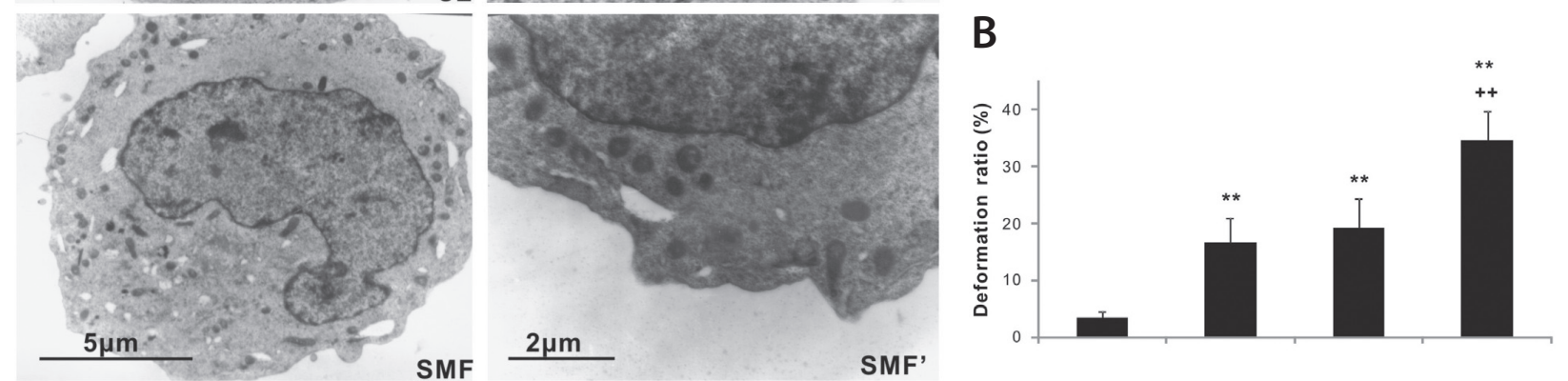

C
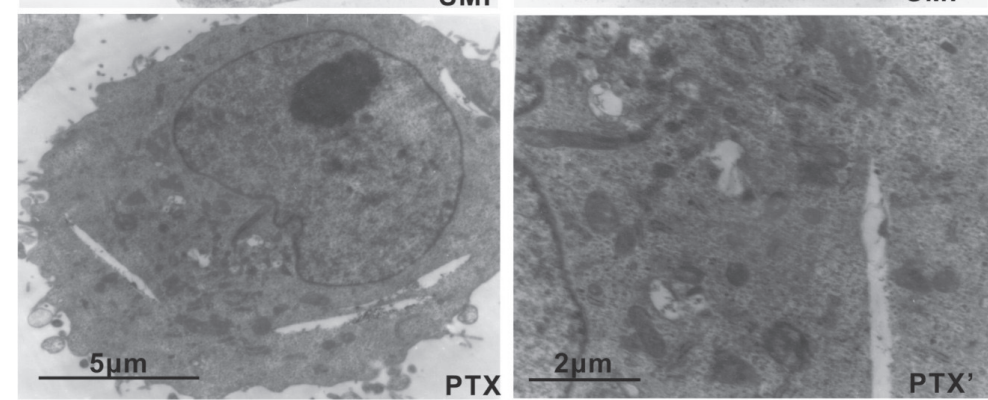

d

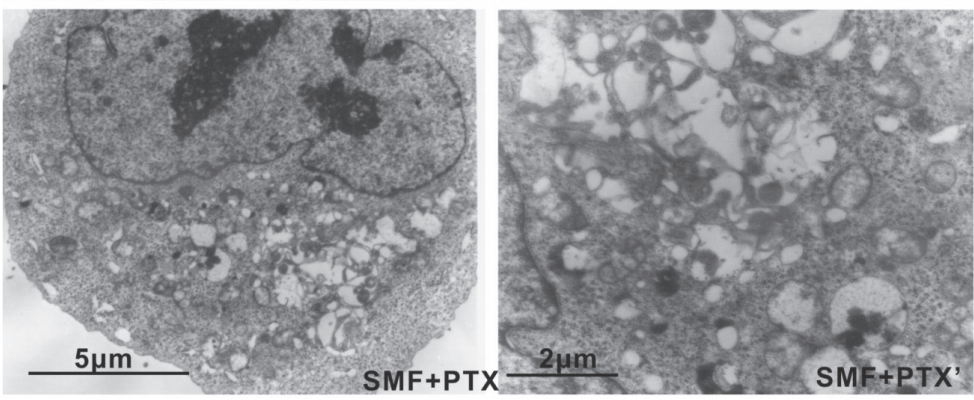

Figure 7. A. Effect of $8.8 \mathrm{mT}$ SMF combined with paclitaxel on cell organelle ultrastructure of K562 cells. The magnification of left images is $4000 \times$. The magnification of right images is $10000 \times$. The cell membrane of controls was integrated (a). Small vacuoles and many strongly stained granules were randomly distributed in the cytoplasm after the cells were exposed to SMF for $24 \mathrm{~h}(\mathrm{~b})$. In the paclitaxel group, strip-like vacuoles and a few deeply stained cystidiform structures were observed in the cytoplasm (c). In the SMF+paclitaxel group, the number of different-sized vacuoles in the cytoplasm was increased (d). B. The quantitative data of the TEM observation on K562 cells. ${ }^{* *} p<0.01$ compared with the controls; $++p<0.01$ compared with other three groups; $n=50$.

structure. Besides cellular DNA, cell membrane was also sensitive to SMF and paclitaxel.

Although our present study revealed that the SMF can enhance the effect of antineoplastic drugs, paclitaxel, on cancer cells with a combined treatment of SMFs and chemotherapeutic drugs. However, so far it remains unclear whether such kind of synergistic effect is suit for other tumor cells and whether the combined treatment of SMFs and anticancer drugs affect the normal cells. All these doubts need additional experiment to prove, this will be our future researches.

\section{Conclusion}

In recent years, a fascinating new area is the coupling of SMF exposure with possible chemotherapy (Gray et al. 2000; Tofani et al. 2003). However, our understanding about cytotoxic effects of SMF and chemotherapeutic agent on tumor cells remains limited. In order to better understand the mechanism of these cytotoxic effects, more investigations are required. Our results indicate that the killing effects of SMF and paclitaxel are more efficient than those of SMF or paclitaxel alone. These effects may correlate with DNA dam- 
age induced by SMF and paclitaxel, resulting in G2/M phase arrest. Moreover, the combination of SMF and paclitaxel not only enhances organelle structure lesion but also modifies the cell surface fine structure.

Acknowledgement. This work was supported by Grants from the National Natural Science Foundation of China (No. 20772077), the National Basic Research Priorities Program of China (No. 104167) and the Fundamental Research for the Central universities (No. GK200902033).

\section{References}

Baureus Koch C. L., Sommarin M., Persson B. R., Salford L. G., Eberhardt J. L. (2003): Interaction between weak low frequency magnetic fields and cell membranes. Bioelectromagnetics 24, 395-402 http://dx.doi.org/10.1002/bem.10136

Bersani F., Marinelli F., Ognibene A., Matteucci A., Cecchi S., Santi S., Squarzoni S., Maraldi N. M. (1997): Intramembrane protein distribution in cell cultures is affected by $50 \mathrm{~Hz}$ pulsed magnetic fields. Bioelectromagnetics 18, 463-469 http://dx.doi.org/10.1002/(SICI)1521-186X(1997)18:7<463:: AID-BEM1>3.0.CO;2-0

Chen W. F., Qi H., Sun R. G., LiuY., Zhang K., Liu J. Q. (2010): Static magnetic fields enhanced the potency of cisplatin on k562 cells. Cancer Biother. Radiopharm. 25, 401-408 http://dx.doi.org/10.1089/cbr.2009.0743

Chionna A., Dwikat M., Panzarini E., Tenuzzo B., Carla E. C., Verri T., Pagliara P., Abbro L., Dini L. (2003). Cell shape and plasma membrane alterations after static magnetic fields exposure. Eur. J. Histochem. 47, 299-308

Collins A. R. (2004): The comet assay for DNA damage and repair: principles, applications, and limitations. Mol. Biotechnol. 26, 249-261 http://dx.doi.org/10.1385/MB:26:3:249

Grassi C., D’Ascenzo M., Torsello A., Martinotti G., Wolf F., Cittadini A., Azzena G. B. (2004): Effects of $50 \mathrm{~Hz}$ electromagnetic fields on voltage-gated $\mathrm{Ca} 2+$ channels and their role in modulation of neuroendocrine cell proliferation and death. Cell Calcium 35, 307-315 http://dx.doi.org/10.1016/j.ceca.2003.09.001

Gray J. R., Frith C. H., Parker J. D. (2000): In vivo enhancement of chemotherapy with static electric or magnetic fields. Bioelectromagnetics 21, 575-583 http://dx.doi.org/10.1002/1521-186X(200012)21:8<575::AID-BEM3>3.0.CO;2-F

Gundersen G. G. (2002): Evolutionary conservation of microtubule-capture mechanisms. Nat. Rev. Mol. Cell Biol. 3, 296-304 http://dx.doi.org/10.1038/nrm777

Hannan C. J. Jr., Liang Y., Allison J. D., Searle J. R. (1994): In vitro cytotoxicity against human cancer cell lines during pulsed magnetic field exposure. Anticancer Res. 14, 1517-1520

Hellman B., Vaghef H., Bostrom B. (1995): The concepts of tail moment and tail inertia in the single cell gel electrophoresis assay. Mutat. Res. 336, 123-131
Hofmann G. A., Dev S. B., Dimmer S., Nanda G. S. (1999): Electroporation therapy: a new approach for the treatment of head and neck cancer. IEEE Trans. Biomed. Eng. 46, 752-759 http://dx.doi.org/10.1109/10.764952

Horwitz S. B., Lothstein L., Manfredi J. J., Mellado W., Parness J., Roy S. N., Schiff P. B., Sorbara L., Zeheb R. (1986): Taxol: mechanisms of action and resistance. Ann. NY. Acad. Sci. 466, 733-744 http://dx.doi.org/10.1111/j.1749-6632.1986.tb38455.x

Horwitz S. B. (1992): Mechanism of action of taxol. Trends Pharmacol. Sci. 13, 134-136 http://dx.doi.org/10.1016/0165-6147(92)90048-B

Jordan M. A., Toso R. J., Thrower D., Wilson L. (1993): Mechanism of mitotic block and inhibition of cell proliferation by taxol at low concentrations. Proc. Natl. Acad. Sci. USA. 90, 9552-9556 http://dx.doi.org/10.1073/pnas.90.20.9552

Kastan M. B., Bartek J. (2004): Cell-cycle checkpoints and cancer. Nature 432, 316-323 http://dx.doi.org/10.1038/nature03097

Konca K., Lankoff A., Banasik A., Lisowska H., Kuszewski T., Gozdz S., Koza Z., Wojcik A. (2003): A cross-platform public domain PC image-analysis program for the comet assay. Mutat. Res. 534, 15-20

Kumar N. (1981): Taxol-induced polymerization of purified tubulin. Mechanism of action. J. Biol. Chem. 256, 10435-10441

Liu Q., Sun S., Xiao Y., Qi H., Shang Z., Zhang J., Ren Y., Li M., Li Q. (2003): Study of cell killing and morphology on S180 by ultrasound activating hematoporphyrin derivatives. Sci. China C Life Sci. 46, 253-262

Mosmann T. (1983): Rapid colorimetric assay for cellular growth and survival: application to proliferation and cytotoxicity assays. J. Immunol. Methods 65, 55-63

http://dx.doi.org/10.1016/0022-1759(83)90303-4

Mundy D. I., Machleidt T., Ying Y. S., Anderson R. G., Bloom G. S. (2002): Dual control of caveolar membrane traffic by microtubules and the actin cytoskeleton. J. Cell Sci. 115, 4327-4339 http://dx.doi.org/10.1242/jcs.00117

Olsson G., Belyaev I.Y., Helleday T., Harms-Ringdahl M. (2001): ELF magnetic field affects proliferation of SPD8/V79 Chinese hamster cells but does not interact with intrachromosomal recombination. Mutat Res 493, 55-66

Pushkarev V. M., Starenki D. V., Saenko V. A., Namba H., Kurebayashi J., Tronko M. D., Yamashita S. (2004): Molecular mechanisms of the effects of low concentrations of taxol in anaplastic thyroid cancer cells. Endocrinology 145, 3143-3152 http://dx.doi.org/10.1210/en.2004-0127

Qi H., Chen W., Ai X., Wei Q., Liu Y., Zhang K., Sun R. (2011): Effects of static magnetic fields and adriamycin on k562 cells. Bioelectromagnetics 32, 191-199 http://dx.doi.org/10.1002/bem.20625

Rao S., Horwitz S. B., Ringel I. (1992): Direct photoaffinity labeling of tubulin with taxol. J. Natl. Cancer Inst. 84, 785-788 http://dx.doi.org/10.1093/jnci/84.10.785

Revenu C., Athman R., Robine S., Louvard D. (2004): The co-workers of actin filaments: from cell structures to signals. Nat. Rev. Mol. Cell Biol. 5, 635-646 
http://dx.doi.org/10.1038/nrm1437

Ruiz-Gomez M. J., de la Pena L., Prieto-Barcia M. I., Pastor J. M., Gil L., Martinez-Morillo M. (2002): Influence of 1 and $25 \mathrm{~Hz}$, $1.5 \mathrm{mT}$ magnetic fields on antitumor drug potency in a human adenocarcinoma cell line. Bioelectromagnetics 23, 578-585 http://dx.doi.org/10.1002/bem.10054

Sabo J., Mirossay L., Horovcak L., Sarissky M., Mirossay A., Mojzis J. (2002): Effects of static magnetic field on human leukemic cell line HL-60. Bioelectrochemistry 56, 227-231 http://dx.doi.org/10.1016/S1567-5394(02)00027-0

Smith O. M., Goodman E. M., Greenebaum B., Tipnis P. (1991) An increase in the negative surface charge of U937 cells exposed to a pulsed magnetic field. Bioelectromagnetics 12, 197-202 http://dx.doi.org/10.1002/bem.2250120307

Tofani S., Barone D., Berardelli M., Berno E., Cintorino M., Foglia L., Ossola P., Ronchetto F., Toso E., Eandi M. (2003): Static and
ELF magnetic fields enhance the in vivo anti-tumor efficacy of cis-platin against lewis lung carcinoma, but not of cyclophosphamide against B16 melanotic melanoma. Pharmacol. Res. 48, 83-90

Wolf F. I., Torsello A., Tedesco B., Fasanella S., Boninsegna A., D’Ascenzo M., Grassi C., Azzena G. B., Cittadini A. (2005): $50-\mathrm{Hz}$ extremely low frequency electromagnetic fields enhance cell proliferation and DNA damage: possible involvement of a redox mechanism. Biochim. Biophys. Acta 1743, 120-129 http://dx.doi.org/10.1016/j.bbamcr.2004.09.005

Zhuang L. N., Qi H., Sun R. G., Chen W. F., Liu Y., Zhu J. (2005): Real time observation on cells in different fixed conditions and living cells in buffer solution by AFM. Acta Biophysica Sinica 21, 345-350

Received: March 3, 2011

Final version accepted: October 11, 2011 